\title{
Outbreak of Lumpy Skin Disease of Cattle in South-West Part of Bangladesh and its Clinical Management
}

\section{Dibyendu Biswas $^{1 *}$, Shib Shankar Saha ${ }^{2}$, Shankar Biswas ${ }^{3}$ and Md. Abu Sayeed ${ }^{4}$}

${ }^{1}$ Department of Medicine, Surgery and Obstetrics, Faculty of Animal Science and Veterinary Medicine, Patuakhali Science and Technology University, Barishal Campus, Babugonj, Barishal, Bangladesh; ${ }^{2}$ Department of Pathology and Parasitology, Faculty of Animal Science and Veterinary Medicine, Patuakhali Science and Technology University, Barishal Campus, Babugonj, Barishal, Bangladesh; ${ }^{3} J a g o r a n i$ Chakro Foundation, Jessore, Bangladesh; ${ }^{4}$ Department of Medicine, Jhenaidah Government Veterinary College, Jhenaidah, Bangladesh.

Abstract | Lumpy skin disease (LSD) is a highly infectious eruptive viral disease of cattle, caused by LSD virus (LSDV) under the family Poxviridae and transmitted by direct contact or through biological vectors such as mosquitoes, flies and ticks. Sporadic cases of LSD have been observed in cattle elsewhere. The aim of the present study was undertaken to evaluate the present scenario of LSD and its clinical management at different house-holds at south-west region of Bangladesh. A structured questionnaire was developed and data were collected from the two upazila (Monirampur and Abhaynagar) at Jessore district. A total of 52 small house-holds and 183 cattle were observed the study period from 15 June to 15 August 2019. LSD was diagnosed on the basis of present clinical signs guided by the OIE manual. All data were analyzed by Epi Info 7 and SPSS statistical software. Analyzed data revealed that young female cattle were mostly susceptible to this disease. Poor intra-herd hygienic conditions and managemental practices could aggravate the disease manifestation. Contrarily, no significant difference was observed in between good and medium quality intraherd level hygienic environments. Five different treatment protocols were applied for recovery of the affected cows; where no significant differences were estimated among the treatment protocol in contrast to recovery from LSD. However, dexamethasone, chlorpheniramine maleate, combination of oxytetracycline and meloxicam showed apparently good results. Interestingly, most of the household in this study area never used mosquito curtains at their cattle house at the night. From this data, it was concluded that LSD affects both sex of animals and young female are most susceptible. Poor intra-herd hygienic conditions and managemental practices could act as a cofactor for disease occurrence. Further researches are needed to find out better clinical management of LSD, identification of risk factor and molecular characteristics of this disease in Bangladesh.

Editor | Muhammad Abubakar, National Veterinary Laboratories, Park Road, Islamabad, Pakistan.

Received | July 02, 2020; Accepted | July 29, 2020; Published | August 21, 2020

*Correspondence | Dibyendu Biswas, Deptartment of Medicine, Surgery and Obstetrics, Patuakhali Science and Technology University, Barishal Campus, Barishal-8210, Bangladesh; Email: dipupstu2012@pstu.ac.bd

Citation | Biswas, D., S.S. Saha, S. Biswas and M.A. Sayeed. 2020. Outbreak of lumpy skin disease of cattle in south-west part of bangladesh and its clinical management. Veterinary Sciences: Research and Reviews, 6(2): 100-108.

DOI | http://dx.doi.org/10.17582/journal.vsrr/2020.6.100.108

Keywords | LSD, Mosquitoes, Dexamethasone, Oxytetracycline, Poxviridae

\section{Introduction}

L umpy skin disease (LSD) is an important deconomically devastating emerging viral disease of cattle and water buffalo. The World Organization for Animal Health (OIE) categorizes LSD as a notifiable disease because of the substantial economic impact and rapid transboundary spreading in 
nature (Tuppurainen and Oura, 2012). Under the family of poxviridae, genus capripox virus has three members namely sheep pox, goat pox and lumpy skin disease viruses which infect sheep, goats and cattle, respectively. Poxviruses are double-stranded DNA viruses in which the ends of the genome consist of terminal hairpin loops. Poxvirus can be identified by its distinct morphology of brick-shaped appearance under electron microscope (Curry et al., 2006). However, LSD is characterized by sudden appearance of fever and specific nodular skin lesions in the body surface of animals. Skin lesions may vary from only a few lumps to entire body surfaces. LSD infected cattle manifests lymphadenopathy, ocular and nasal discharge, and ulcerative lesions in the oropharyngeal mucous membranes (Brenner et al., 2009). Edematous swellings in the neck, brisket region and in lower legs of cattle together may progress to lameness (Tolera et al., 2019). Economic impact of LSD can be determined directly on availability of vectors, host susceptibility and applied preventive measures. Besides case fatality (does not exceed 3\% in uncomplicated cases), economic impacts are caused by production losses (abrupt losses of milk production) and lower performances in draft animals. An indirect loss of LSD arises from the cost of control efforts such as quarantine of farms, vaccination, medication and human labour; international trade limitation can also be major losses during outbreak (Tuppurainen and Oura, 2014).

The first LSD case was reported in Zambia in 1929 and the disease remained endemic to sub-Saharan Africa until 1990, when its extended into North Africa and then into the Middle East (Ali et al., 1990; Fagbo et al., 2014). More recently, LSD has reported in southeast Europe, with outbreaks in Turkey and Russia (Albayrak et al., 2018; Sevik and Dogan, 2017). Seroprevalence and risk factors of LSD was identified in Ethiopia and Uganda (Abera et al., 2015; Ochwo et al., 2019). Recently molecular characterization has performed in Egypt (Abdallah et al., 2018). It has now been spread to most of the agro-ecological zones of the world (Babiuk et al., 2008a; Gari et al., 2010). Therefore, this disease has the potential for global concern (Tuppurainen and Oura, 2012). Among south Asian countries, recently India has reported LSD outbreak in Chhotanagpur Plateau Region (Singh, 2019).

LSD has reported all seasons of the year; however, disease severity is more in climate having high temperature and humidity such as spring and summer, the peak breeding season for blood feeding vectors. LSD virus is very stable which sustain in the ambient temperature especially in dried scabs for a longer period and can contaminate animal beddings and premises. Severity of the clinical form of LSD depends on the virulence of the virus and the risk factors affecting the susceptibility of the host, such as host immunity, breed and age of cattle. Cattle is considered to be the main natural host for LSD but it can infect other animals such as buffalo and sheep with less severity (Elhaig et al., 2017). LSD virus can be either transmitted by direct contact through fomites or by mechanical transmission through insect or tick vectors. Aedes aegypti, Stomoxys calcitrans, Rhipicephalus appendiculatus has been demonstrated to be an effective mechanical vector for virus transmission (Chihota et al., 2001; Lubinga et al., 2015; Tuppurainen et al., 2011, 2013).

As it is a viral disease, there is no specific drug against LSD. Available supportive therapy can be practiced including an antibiotic to prevent secondary bacterial infection, an anti-inflammatory to reduce feverish condition and an antihistaminic to reduce tissue damage. A wide scale cattle vaccination along with other supportive measures including disinfection and farm biosecurity, stamping-out and movement controls of the affected stock are found effective to combat with the spread of the disease. However, eradication and control policy vary among countries depending on various factors such as climate conditions and local farming practices.

In Bangladesh, LSD was first reported to OIE on September, 2019 and the samples were taken only from Chattogram district (only 3 upazilas) of Chattogram division. The report showed only attack rate among the cattle in the affected upazilas (FAO, 2019). However, there is no published information about LSD outbreak in other areas and effective management practices to cure the disease. Therefore, the present study has investigated the incidence, risk factors and clinical management of LSD in southwest part of Bangladesh.

\section{Materials and Methods}

\section{Description of the study area}

Jessore, a district of Bangladesh situated at southwest part of the country and close to the East Indian 
border. The district comprises with eight upazila (subdistrict), among which 2 different upazila named Monirampur and Abhaynagar was selected for the current study. This district is situated in the most south-west part of Bangladesh and near very close to the East Indian border.

\section{Affected farm visit and data collection}

A pre-structured questionnaire was developed and used as data recording tools during field work. One questionnaire was administered per affected farm or house-holds through questioning to the owner or responsible person of the subsequent farm or household by the investigator. Farm's demographic information included the total number of cattle on the premises, the number of LSD affected cattle and the number of cattle that died due to the disease. Individual sick animals information included the age of animal, sex, the type of animal (lactating cow, dry cow, pregnant heifer, calf and bull), average body coverage with skin nodules, limb swelling, intraherd farm hygiene, use of mosquito curtain and any treatment. After that our prescribed treatment protocol was applied accordingly. According to the OIE manual, the characteristics skin lesions were matched and tentatively diagnosed as LSD. An average skin nodule that covers body surfaces was measured as percentage on the basis of eye estimation.

\section{Applied treatment plan}

For the selection of best clinical management practices of lumpy skin disease in cattle, five treatment plans were applied randomly among infected animals. Each group was treated with different treatment regimen consisting with antihistaminic drugs (pheniramine maleate: pmm), painkiller (dexamethasone: dexa, meloxicam: melox) and antibiotics (oxytetracycline: otc, amoxycilline+Cloxacillin: amcox, gentamicin: gent). Group-1, Group-2, Group-3, Group-4 and Group -5 were treated with dexa+pmm+amcox+melox, dexa+pmm+gent, dexa+pmm+otc + melox dexa+pmm+otc, dexa+pmm+Pen, respectively according to the recommended doses. The treatment was continued for 7 days. Follow up investigation was performed for at least 30 days after treatment started.

\section{Data management and statistical analysis}

After collecting all information, data was recorded in an excel sheet and descriptive analysis was performed by EpiInfo-7 and SPSS. Probability values less than 0.05 were considered to indicate a statistically significant.

\section{Results and Discussion}

Many areas in the world, especially in Africa, LSD is an endemic disease of cattle and infected cattle act as naturals source of infection of this virus (Tuppurainen et al.,2015).It is a very contagious viral disease causing substantial economic losses to the cattle industry. The first time LSD has been reported in several countries of Africa and the Middle East, and recently, it was transmitted to Europe. However, very recently OIE declared the existence of LSD in the Indian subcontinent including India (OIE, 2019a), China (OIE, 2019b) and Bangladesh in 2019 (OIE, 2019c).

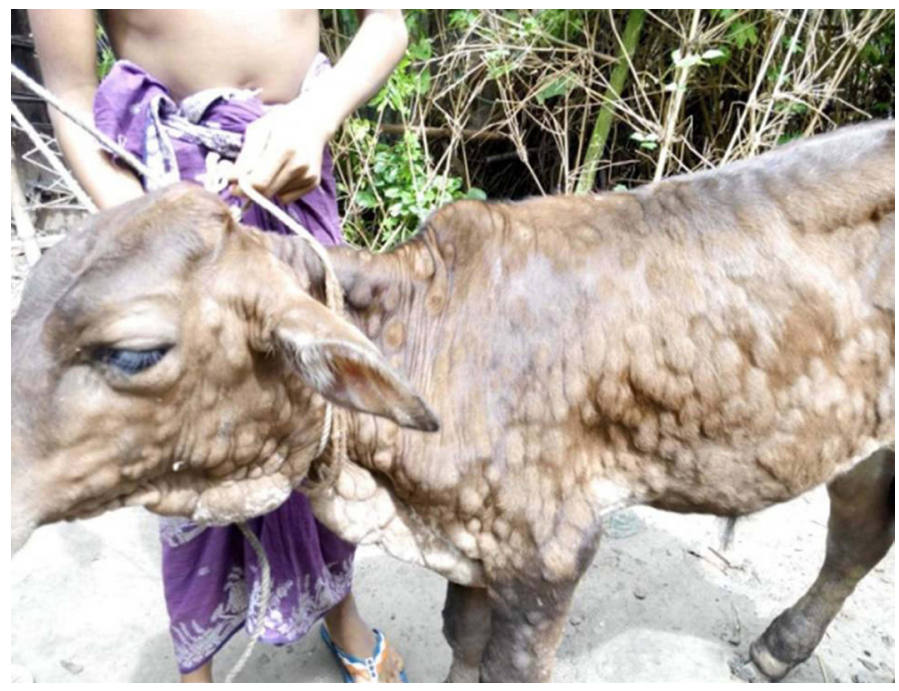

Figure 1: A calf showing characteristic lumpy skin disease with generalized circumscribed active nodular skin lesions covering the entire body surface.

The epidemiological data about LSD in Bangladesh is insufficient. In the present study, LSD was investigated in two areas of south-west region of Bangladesh by applying field study techniques. The study was conducted at Monirampur and Abhaynagar upazila of Jessore District from 15 June to 15 August 2019 among 52 small house-holds cattle farmers and total of 183 cattle were observed. In the present, the suspected LSD cattle $(\mathrm{N}=183)$ appeared small-sized nodules $(15-45 \mathrm{~mm})$ on the entire body surfaces (Figure 1) mainly on the neck and trunk region. The nodules involve both epidermis and dermis layer of skin and they were raised. The epidermal micro vesicles were coalesced into large vesicles that were quickly ruptured and found ulcerated area which might be severely infected with other pathogens causing bacterial pneumonia, tracheal stenosis, mastitis with secondary bacterial infection (E1-Neweshy et al., 2013). The ulcerated nodules were healed very slowly and the affected animals often remain debilitated for 
several months. The average rectal temperature was 103 to $106.6^{\circ} \mathrm{F}$, accompanied with leg edema especially at hock region with moderate lymphadenopathy (data not shown). Regional lymph nodes became enlarged up to 10 times, edematous, congested and cellulitis (Salib and Osman, 2011).

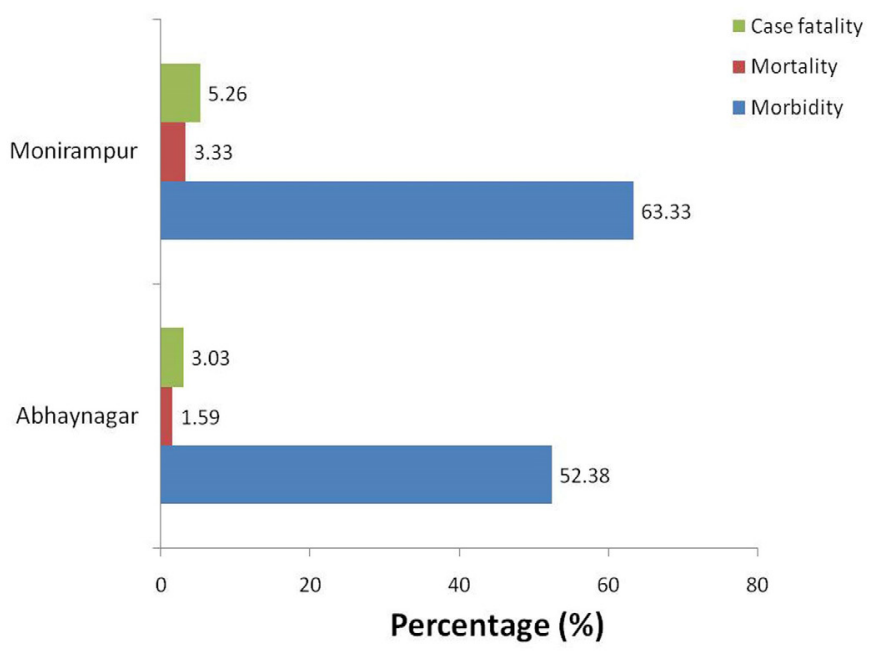

Figure 2: Morbidity rate, mortality rate and case fatality rate of lumpy skin disease of cattle in study areas.

In this study, it was found that about $63.33 \%$ and $52.38 \%$ of cattle were affected with LSD in Monirampur and Avoynagor upazila, respectively (Figure 2). However, during this study the mortality rate was recorded at 1.59\% in Abhaynagar and 3.33\% in Monirampur, (Figure 2). Morbidity and mortality depend on cattle breed, host susceptibility, herd immune status and activity of insects/mechanical vectors involved in the transmission of the virus (CFSPH, 2011). However, biting flies/mosquitoes are the main mechanical vectors of this disease and their population is increased between July to October in tropical countries like Bangladesh (Gumbe, 2018). Overall morbidity of LSD varied from 2 to $85 \%$ or higher but in our case the morbidity was lower which might be due to less number of studied animals and difference in duration of the study. In the endemic area the morbidity rate usually around $10 \%$ which produce heavy economic loss due to having a high morbidity rate (Tuppurainen and Oura, 2012). However, in our report, the average mortality rate was $2.73 \%$ (Figure 2) and it was similar to other report (Davies, 1991). The mortality rate was varied from 1 to $5 \%$ in the endemic area (Tuppurainen and Oura, 2012; Babiuk et al., 2008b) and sometimes it can be reached up to $40 \%$ in the epidemic area (Tuppurainen and Oura, 2012). In our study economic analysis was not done but it was reported that the economic losses affected by draught power loss, treatment and vaccination cost which costs about 32 USD per animal (Gari et al., 2010).

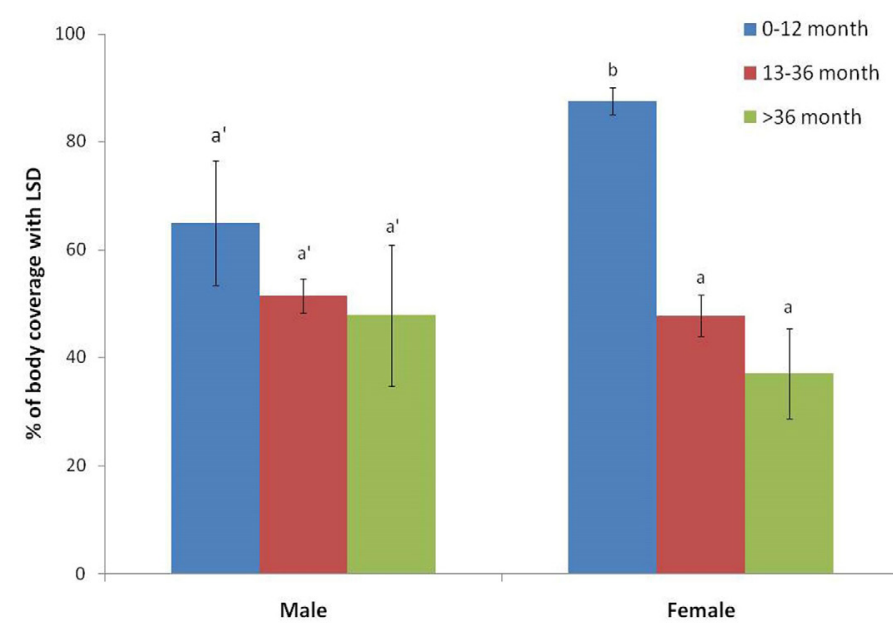

Figure 3: Average body surface coverage with skin nodules of different age categories of male and female cattle under study area. The data are presented as the mean $\pm S E M$. Bars with different letters within the respective endpoint differ from each other statistically significant ( $p<$ 0.05).

Among the studied cattle it was found that young female animals (13-36 months) were more susceptible (39.24\%) to LSD infection than other age groups and it was significantly $(\mathrm{P}<0.05)$ higher than early and older age group (Table 1). A similar result was reported in a seroprevalence study conducted in Uganda (Ochwo et al., 2019) reported highest number of cases among >25 months of aged female cows than male cattle. The more infection is due to duration of exposure of this virus which increases the chance of infection. High yielding cows can contribute to the severity of the disease in Holstein-Friesian cattle (Tageldin et al., 2014). The young male cattle also got this infection but have no significant difference between the different age categories. Although compared with the male and female cattle instead of age, male animals got insignificantly more infection than females. The region behind that, male animals were fatigue from heavy work rather than biological work (Abera et al., 2015; Gari et al., 2010) and draft male animals cannot protect themselves well from the biting flies during harnessed in the yolk and ploughing; at that time biting flies may transmit LSD infection by attaching themselves in the host body. In the contrary, both male and female calves got less infection as compared with other age groups (Table 1). This might be due to calves were kept at close confinement with extra care that makes it away from biting flies (Magori-Cohen et al., 2012). Poor intra-herd hygiene and bad management conditions produce more favorable environment for mechanical 
vectors like flies and mosquitoes. In our report, it was found that high proportion of cattle (47.54\%) affected with LSD infection in poor hygienic management practicing house-holds compared to good (2.73\%) and medium (9.29\%) hygienic management practicing house-holds (Table 3). Poor bio-security practices, farm waste management, high density of biting fly around the feedlot are the main possible cause of transmission of this virus (Alemayehu et al., 2015). Recently, it was found that intra-herd insect control and insufficient vaccination are the possible cause of transmission of LSD (Kumar, 2011). Surprisingly, our report was very similar to that point that most of the animal owners $(97.81 \%)$ in the study did not use mosquito-curtain at night in their cattle house (Figure 4). Mosquito net, fly proof system, smoke released can protect the farm animals form biting fly and mosquito (Desquesnes et al., 2013).

Table 1: Distribution of lumpy skin disease according to sex, age in the study area.

\begin{tabular}{lllllll}
$\begin{array}{l}\text { Varia- } \\
\text { ble }\end{array}$ & $\begin{array}{l}\text { Age } \\
\text { category ber examined }\end{array}$ & \multicolumn{2}{c}{$\begin{array}{l}\text { Total num- } \\
\text { affected (\%) }\end{array}$} & $\begin{array}{l}\text { No. of animals } \\
\text { value }\end{array}$ & $\begin{array}{l}\text { P- } \\
\text { value }\end{array}$ \\
Male & $0-12$ & 9 & $7(6.73)$ & 2.44 & 0.296 \\
& $13-36$ & 80 & $50(48.08)$ & & \\
& $>36$ & 15 & $7(6.73)$ & & \\
Female & $0-12$ & 3 & $2(2.53)$ & 6.94 & 0.031 \\
& $13-36$ & 45 & $31(39.24)$ & & \\
& $>36$ & 31 & $12(15.19)$ & & \\
\hline
\end{tabular}

Table 2: Limb swelling according to different age category of infected cattle in the affected area.

\begin{tabular}{|lllll|}
$\begin{array}{l}\text { Age of animal } \\
\text { (month) }\end{array}$ & $\begin{array}{l}\text { Total animal } \\
\text { examined }\end{array}$ & $\begin{array}{l}\text { Limb } \\
\text { swelling (\%) }\end{array}$ & $\begin{array}{l}\boldsymbol{\chi 2} \\
\text { value }\end{array}$ & $\begin{array}{l}\text { P- } \\
\text { value }\end{array}$ \\
$0-12$ & 12 & $4(2.19)$ & 6.04 & 0.048 \\
$13-36$ & 125 & $22(12.02)$ & & \\
$>36$ & 46 & $3(1.64)$ & & \\
\hline
\end{tabular}

Table 3: Effects of intra-herd farm hygiene on Lumpy Skin Disease occurrence of cattle in the affected area.

\begin{tabular}{|c|c|c|c|c|c|}
\hline Variable & Category & $\begin{array}{l}\text { Animal } \\
\text { tested (N) }\end{array}$ & $\begin{array}{l}\text { No. of posi- } \\
\text { tive (\%) }\end{array}$ & $\begin{array}{l}\chi^{2} \\
\text { Value }\end{array}$ & $\begin{array}{l}\text { P- } \\
\text { Value }\end{array}$ \\
\hline \multirow{3}{*}{$\begin{array}{l}\text { Farm } \\
\text { hygiene }\end{array}$} & Good & 9 & $5(2.73)$ & \multirow[t]{3}{*}{0.46} & \multirow[t]{3}{*}{0.793} \\
\hline & Medium & 26 & $17(9.29)$ & & \\
\hline & Poor & 148 & $87(47.54)$ & & \\
\hline
\end{tabular}

In this study, it was found that the highest (12.02\%) limb swelling was recorded in LSD positive young (1 year- 3 years) cattle and it was significantly different from other age groups (Table 2). Limb swelling and lameness were also seen in LSD infected cattle and the cattle was reluctant to move (Gelagay et al., 2015; Tassew et al., 2018). Lameness might be due to deep intradermal or intramuscular ulcerative skin nodules extending on to tendon and tendon sheath (Tuppurainen et al., 2018) causing arthritis (Ahmed and Zaher, 2008). Sometimes, swelling beside the joints and cellulitis or phelgmone causes arthritis and lameness in cattle (Salib and Osman, 2011). However, such variation of limb swelling could be attributed to age specific lesions.

Yes No

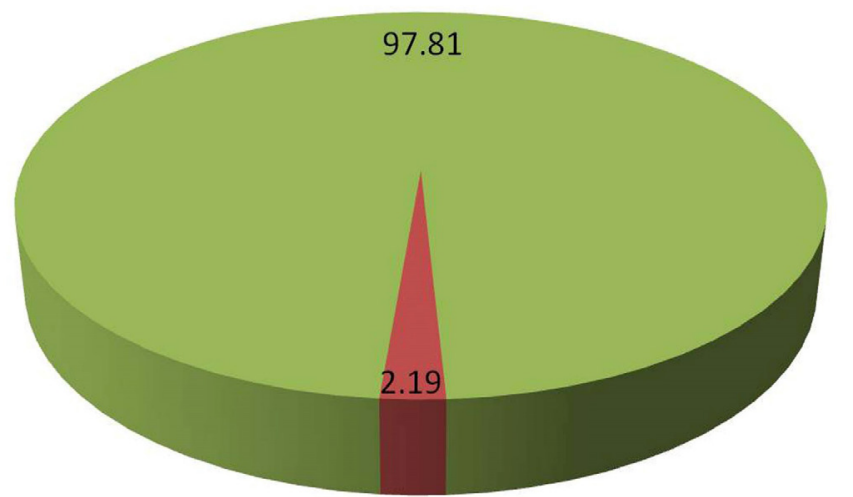

Figure 4: Pie chart showing use of mosquito curtain in cattle house at night in the study area.

The numbers of skin nodules were varied among affected animals. After biting with infected insets LSD virus replicated in the blood and skin cells until viremia is detectable at usually 6 days post infection and around 7 days post-inoculation, skin nodules start to appear on the surface. High levels of virus are found in the skin lesions and in the blood, which might be important for mechanical transmission through insects to other healthy animals. However, LSD is scarcely transmitted by direct contact (Tageldin et al., 2014; Hunter and Wallace, 2001). The skin nodules were found in all portion of body but mostly found in neck and body (Abutarbush et al., 2015). The number of skin nodules depends on tissue injuries including vasculitis with concomitant thrombosis and infraction. Multiple virus-encoded products are formed during the LSD virus infection and may causes more skin nodules formation. In this study, it was found that skin nodules covered about $65 \%$ and $87.5 \%$ body surface in up to 12 months of age group of male and female cattle, respectively. But most significantly $(p<0.05)$, the skin nodules occupied most of the body surface in the female calf with an age of 0-12 month 
(Figure 3). In natural infection, the very young calves are more sensitive to this disease and causes severe skin lesions. The intense severity of lesion may be due to low transfer of humoral immunity and ill health (Coetzer and Tuppurainen, 2004), however, the exact reasons are needed to be discovered.

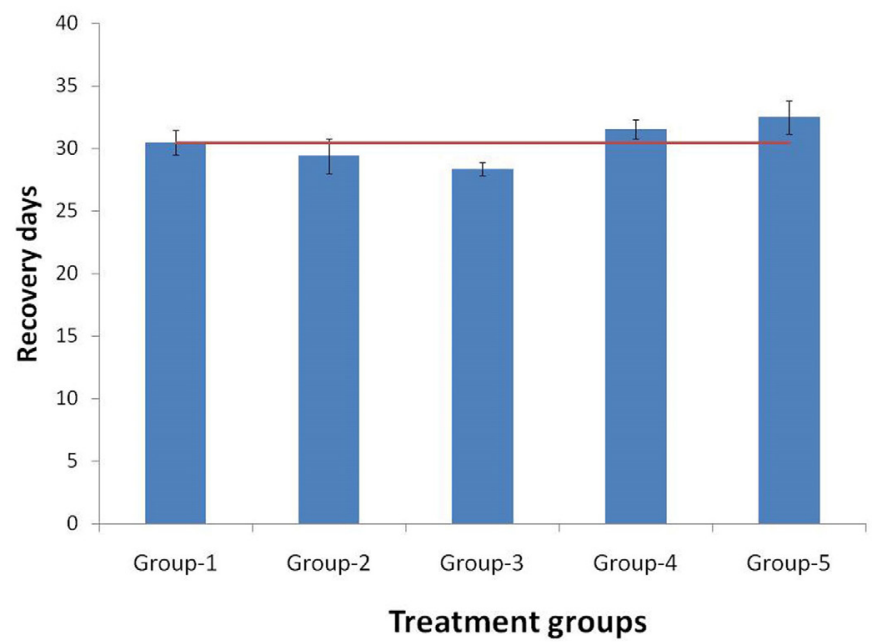

Figure 5: Duration of recovery after the treatment responses of LSD suspected patient towards different treatment pattern. The data are presented as the mean \pm SEM. Statistical significant were considered as $P<0.05$. The horizontal bar indicates the average duration of recovery after treatment. Group-1: Dexa+Antibis+Amcox+Melox; Group-2: Dexa+Antibis+gen; $\quad$ Group-3: $\quad$ Dexa+Antibis+OTC+Melox; Group-4: Dexa+Antihis+OTC; Group-5: Dexa+Antibis+pen.

The treatment of LSD is only symptomatic to save the animals life as there is no specific treatment for cattle. Therefore, to reduce the secondary LSD complications antibiotics and anti-inflammatory drugs were used (Slib and Osman, 2011). There were so many complications of LSD lesions occurred as described elsewhere (Slib and Osman, 2011; Abutarbush et al., 2015); however, no such complication was found in this study. Therefore, according to recommendation by field veterinary practitioners five treatment strategies were applied. Treatment follow up observed for next 30 days as recovery time is very long (2-4 months) to get back its normal body condition (Slib and Osman, 2011). However, there was no significant $(p>0.05)$ variation among treatment protocol (Figure 5) was observed. The average duration of recovery from this disease was $30.39 \pm 0.45$ days. Here, dexamethasone along with antihistamine, oxytetracycline and meloxicam combined treatment plan recovered LSD infected cattle faster $(28.35 \pm 0.56)$ than other groups. There were good results in cows using $10 \%$ oxytetracycline and dexamethasone together intramuscularly (Feyisa, 2018) and this result is similar to our result. After using these drug lesions such as fever and nodular skin lesions were subsided remarkably. Even though, along with meloxicam gave good results because it reduces inflammation by binding to cyclo-oxygenase-2 receptors (Stock and Coetzee, 2015).

\section{Conclusion}

In conclusion, female cattle were most susceptible to LSD infection. It is not possible to halt the disease spread by culling of all infected animal. So, national awareness program should be announced about this newly emerging LSD infection in dairy industry.

\section{Authors' Contributions}

DB formulated the problem and hypothesis, structured the experimental design, organized, conducted statistical analyses. SSS literature review, and manuscript preparation. SB data collection. MAS conducted statistical analyses. All authors read and approved the final manuscript.

\section{Conflict of Interests}

The authors have declared no conflict of interests.

\section{References}

Abdallah, F.M., El Damaty, H.M. and Kotb, G.F., 2018. Sporadic cases of lumpy skin disease among cattle in Sharkia province, Egypt: Genetic characterization of lumpy skin disease virus isolates and pathological findings. Vet. World. 11(8): 1150-1158. https://doi. org/10.14202/vetworld.2018.1150-1158

Abera, Z., Degefu, H., Gari, G. and Kidane, M., 2015. Sero-prevalence of lumpy skin disease in selected districts of West Wollega zone, Ethiopia. BMC Vet. Res., 11: 135. https://doi. org/10.1186/s12917-015-0432-7

Abutarbush, S.M.,Ababneh,M.M.,Al-Zoubi,I.G., Al-Sheyab, O.M., Al-Zoubi, M.G., Alekish, M.O. and A1-Gharabat, R.J., 2015. Lumpy skin disease in Jordan: Disease emergence, clinical signs, complications and preliminary-associated economic losses. Transbound. Emerg. Dis., 62 (5): 549-554. https://doi.org/10.1111/ tbed.12177

Ahmed, W.M. and Zaher, K.S., 2008. Observations on lumpy skin disease in local Egyptian cows with emphasis on its impact on ovarian function. 
Afr. J. Microbiol. Res., 2: 252-257.

Albayrak,H., Ozan, E., Kadi,H., Cavunt, A., Tamer, C. and Tutuncu, M., 2018. Molecular detection and seasonal distribution of lumpy skin disease virus in cattle breeds in Turkey. Med. Water. 74(3): 175-178. https://doi.org/10.21521/ mw.6081

Alemayehu, G., Leta, S., Eshetu, E. and Mandefro, A., 2015. Incidence of lumpy skin disease and associated risk factors among export-oriented cattle feedlots at Adama District, Central Ethiopia.J.Vet.Med.Anim.Health.7:128-134. https://doi.org/10.5897/JVMAH2014.0357

Ali, A.A., Esmat, M., Attia, H., Selim, A. and Abdel-Hamid, Y.M., 1990. Clinical and pathological studies of lumpy skin disease in Egypt. Vet. Rec., 127(22): 549-550.

Babiuk, S., Bowden, T., Boyle, D., Wallace, D. and Kitching, R.P., 2008a. Capripoxviruses: an emerging world wide threat to sheep goats and cattle. Transbound. Emerg. Dis., 55: 263-272. https://doi.org/10.1111/j.18651682.2008.01043.x

Babiuk, S., Bowden, T.R., Dalman, B., Parkyn, G. and Copps, J., 2008b. Quantification of lumpy skin disease virus following experimental infection in cattle. Transbound. Emerg. Dis., 55: 299-307. https://doi.org/10.1111/j.18651682.2008.01024.x

Brenner, J., Bellaiche, M., Gross, E., Elad, D., Oved, Z., Haimovitz, M., Wasserman, A., Friedgut, O., Stram, Y., Bumbarov, V. and Yadin, H., 2009. Appearance of skin lesions in cattle populations vaccinated against lumpy skin disease: statutory challenge. Vaccine, 27(10): 1500-1503. https:// doi.org/10.1016/j.vaccine.2009.01.020

CFSPH, 2011. Center for food security and public health, Iowa State University, College of Veterinary Medicine. pp. 55-67.

Chihota, C.M., Rennie, L.F., Kitching, R.P. and Mellor, P.S., 2001. Mechanical transmission of lumpy skin disease virus by Aedes aegypti (Diptera: Culicidae). Epidemiol. Infect., 126: 317-321. https://doi.org/10.1017/ S0950268801005179

Coetzer, J.A.W. and Tuppurainen, E., 2004. Lumpy skin disease. In: Infectious diseases of livestock. Oxford University Press, Southern Africa. pp. 1268-1276.

Curry, A., Appleton, H. and Dowsett, B., 2006. Application of transmission electron microscopy to the clinical study of viral and bacterial infections: present and future. Micron, 37(2): 91-106. micron.2005.10.001

Davies, F., 1991. Lumpy skin disease of cattle: A growing problem in Africa and the Near East. World Anim. Rev., 68: 37-42.

Desquesnes, M., Dargantes, A., Lai, D.H., Lun, Z.R., Holzmuller, P. and Jittapalapong, S., 2013. Trypanosoma evansi and Surra: A Review and Perspectives on Transmission, Epidemiology and Control, Impact, and Zoonotic Aspects. Biomed. Res. Int., 2013: 321237. https://doi. org $/ 10.1155 / 2013 / 321237$

Elhaig, M.M., Selim, A. and Mahmoud, M., 2017. Lumpy skin disease in cattle: Frequency of occurrence in a dairy farm and a preliminary assessment of its possible impact on Egyptian buffaloes. Onderstepoort. J. Vet. Res., 84(1): a1393. https://doi.org/10.4102/ojvr.v84i1.1393

El-Neweshy, M.S., El-Shemey, T.M. and Youssef, S.A., 2013. Pathologic and immunohistochemical findings of natural lumpy skin disease in Egyptian cattle. Pak. Vet. J., 33: 60-64.

FAO, 2019. Situation report: Lumpy skin disease in Bangladesh 2019. Available at: https://fscluster. org/bangladesh/document/situation-reportlumpy-skin-disease (accessed 10 May 2020).

Fagbo, S., Coetzer, J.A.W. and Venter, E.H., 2014. Seroprevalence of Rift Valley fever and lumpy skin disease in African buffalo in the Kruger National Park and Hluhluwe-iMfolozi Park, South Africa. J. South Afr. Vet. Assoc., 85(1): 1-8. https://doi.org/10.4102/jsava.v85i1.1075

Feyisa, A.F., 2018. A case report on clinical management of lumpy skin disease in bull. J. Vet. Sci. Technol., 9: 538. https://doi. org/10.4172/2157-7579.1000538

Gari, G., Waret-Szkuta, A., Grosbois, V., Jacquiet, P. and Roger, F., 2010. Risk Factors Associated with observed clinical lumpy skin disease in Ethiopia. Epidemiol. Infect., 138(11): 1657-1666. https://doi.org/10.1017/ S0950268810000506

Gelagye, E., Belay, A., Ayelet, G., Jenberie, S., Yami, M., Loitsch, A., Tuppurainen, E., Grabherr, R., Diallo, A. and Lamien, C.E., 2015. Capripox disease in Ethiopia: Genetic differences between field isolates and vaccine strain, and implications for vaccination failure. Antiviral 
Res., 119: 28-35. https://doi.org/10.1016/j. antiviral.2015.04.008

Gumbe, A.A.F., 2018. Review on lumpy skin disease and its economic impacts in Ethiopia. J. Dairy Vet. Anim. Res., 7 (2):39-46. https://doi. org/10.15406/jdvar.2018.07.00187

Hunter, P. and Wallace, D., 2001. Lumpy skin disease in southern Africa: a review of the disease and aspects of control. J. S. Afr. Vet. Assoc., 72: 68-71. https://doi.org/10.4102/ jsava.v72i2.619

Kumar, S.M., 2011. An outbreak of lumpy skin disease in a Holstein dairy herd in Oman: A clinical report. Asian J. Anim. Vet. Adv., 6: 851-859. https://doi.org/10.3923/ ajava.2011.851.859

Lubinga, J.C., Tuppurainen, E.S., Mahlare, R., Coetzer, J.A., Stoltsz, W.H. and Venter, E.H., 2015. Evidence of transstadial and mechanical transmission of lumpy skin disease virus by Amblyomma hebraeum ticks. Transbound. Emerg. Dis., 62: 174-182. https://doi. org/10.1111/tbed.12102

Magori-Cohen, R., Louzoun, Y., Herziger, Y., Oron, E., Arazi, A., Tuppurainen, E., Shpigel, N.Y. and Klement, E., 2012. Mathematical modelling and evaluation of the different routes of transmission of lumpy skin disease virus. Vet. Res., 43(1): 1-13. https://doi. org/10.1186/1297-9716-43-1

OIE, 2019a. Event summary: Lumpy skin disease, India. Available from: https://www.oie.int/ wahis_2/public/wahid.php/Reviewreport/ Review/viewsummary? reportid $=32387$

OIE, 2019b. Event summary: Lumpy skin disease, China. Available from: https://www.oie.int/ wahis_2/public/wahid.php/Reviewreport/ Review/viewsummary? reportid $=31501$

OIE, 2019c. Event summary: Lumpy skin disease, Bangladesh; Available from: https://www.oie. int/wahis_2/public/wahid.php/Reviewreport/ Review/viewsummary? reportid $=31742$

Ochwo, S., Vander-Waal, K., Munsey, A., Nkamwesiga, J., Ndekezi, C., Auma, E. and Mwiine, F.N., 2019. Seroprevalence and risk factors for lumpy skin disease virus seropositivity in cattle in Uganda. BMC Vet. Res., 15(1): 236. https://doi.org/10.1186/s12917-019-1983-9

Salib, F.A. and Osman, A.H., 2011. Incidence of lumpy skin disease among Egyptian cattle in Giza Governorate, Egypt. Vet. World,
4 (4): 162-167. https://doi.org/10.5455/ vetworld.2011.162-167

Sevik, M. and Doğan, M., 2017. Epidemiological and molecular studies on lumpy skin disease outbreaks in Turkey during 2014-2015. Transbond. Emerg. Dis., 64 (4): 1268-1279. https://doi.org/10.1111/tbed.12501

Singh, R., 2019. Outbreak of lumpy skin disease (LSD) in cattle in chhotanagpur plateau region (India). Pashudhan praharee (http://www. pashudhanpraharee.com)

Stock, L.M. and Coetzee, J.F., 2015. Clinical pharmacology of analgesic drugs in cattle. Vet. Clin. North Am. Food Anim. Pract., 31(1): 113-138. https://doi.org/10.1016/j. cvfa.2014.11.002

Tageldin, M.H., Wallace, D.B., Gerdes, G.H., Putterill, J.F., Greyling, R.R., Phosiwa, M.N., Al-Busaidy, R.M. and Al-Ismaaily, S.I., 2014. Lumpy skin disease of cattle: an emerging problem in the Sultanate of Oman. Trop. Anim. Health Prod., 46: 241-246. https://doi. org/10.1007/s11250-013-0483-3

Tassew, A., Assefa, A., Gelaye, E., Bayisa, B. and Ftiwi, M., 2018. Identification and molecular characterization of lumpy skin disease virus in East Hararghe and East Shoa Zone, Oromia Regional State. ARC J. Anim. Vet. Sci., 4(3): 1-16.

Tolera, T., Tagesu, A., Roba, H., Gemachu, R. and Getachew, T., 2019. Review on blackleg in cattle. Dairy Vet. Sci. J., 9(5): 555771. https:// doi.org/10.19080/JDVS.2019.09.555771

Tuppurainen, E. and Oura, C., 2014. Lumpy skin disease: An African cattle disease getting closer to the EU. Vet. Rec., 175(12): 300-301. https:// doi.org/10.1136/vr.g5808

Tuppurainen, E.S., Lubinga, J.C., Stoltsz, W.H., Troskie, M., Carpenter, S.T., Coetzer, J.A., Venter, E.H. and Oura, C.A., 2013. Evidence of vertical transmission of lumpy skin disease virus in Rhipicephalus decoloratus ticks. Ticks Tick Borne Dis., 4: 329-333. https://doi. org/10.1016/j.ttbdis.2013.01.006

Tuppurainen, E.S., Stoltsz, W.H., Troskie, M., Wallace, D.B., Oura, C.A., Mellor,P.S., Coetzer, J.A. and Venter, E.H., 2011. A potential role for ixodid (hard) tick vectors in the transmission of lumpy skin disease virus in cattle. Transbound. Emerg. Dis., 58: 93-104. https://doi. org/10.1111/j.1865-1682.2010.01184.x 
Tuppurainen, E.S., Venter, E.H., Coetzer, J.A. and Bell-Sakyi, L., 2015. Lumpy skin disease: Attempted propagation in tick cell lines and presence of viral DNA in field ticks collected from naturally-infected cattle. Ticks Tick Borne Dis., 6: 134-140. https://doi.org/10.1016/j. ttbdis.2014.11.002

Tuppurainen, E.S.M. and Oura, C.A.L., 2012.
Review: lumpy skin disease: an emerging threat to Europe, the Middle East and Asia. Transbound. Emerg. Dis., 59(1): 40-48. https:// doi.org/10.1111/j.1865-1682.2011.01242.x

Tuppurainen, E.S.M., Babiuk, S. and Klement, E., 2018. Lumpy skin disease. Springer International Publishing AG, pp. 65-70. https://doi.org/10.1007/978-3-319-92411-3 